\title{
The Properties of Survey-Based Inflation Expectations in Sweden*
}

Thomas Jonsson ${ }^{\#}$

Pär Österholm*

\footnotetext{
* We are grateful to Meredithy Beechey and seminar participants at the National Institute of Economic Research and Sveriges Riksbank for valuable comments on this paper.

\# National Institute of Economic Research, Box 3116, 10362 Stockholm, Sweden e-mail: thomas.jonsson@konj.se Phone: +46 84535934

* National Institute of Economic Research, Box 3116, 10362 Stockholm, Sweden e-mail: par.osterholm@konj.se Phone: +46 84535972
} 
NIER prepares analyses and forecasts of the Swedish and international economy and conducts related research. NIER is a government agency accountable to the Ministry of Finance and is financed largely by Swedish government funds. Like other government agencies, NIER has an independent status and is responsible for the assessments that it publishes.

The Working Paper series consists of publications of research reports and other detailed analyses. The reports may concern macroeconomic issues related to the forecasts of the institute, research in environmental economics, or problems of economic and statistical methods. Some of these reports are published in their final form in this series, whereas others are previews of articles that are subsequently published in international scholarly journals under the heading of Reprints. Reports in both of these series can be ordered free of charge. Most publications can also be downloaded directly from the NIER home page. 


\begin{abstract}
This paper assesses the properties of survey-based inflation expectations in Sweden. The survey is conducted by Prospera once every quarter and consists of respondents from businesses and labour-market organisations. The paper shows that inflation expectations measured in this survey tend to be biased and inefficient forecasts of future inflation. Results also indicate that long-run inflation expectations are overly adaptive with respect to actual inflation. Finally, evaluations of forecast accuracy show that these inflation expectations are worse predictors of inflation than those of a professional forecasting institution and also typically outperformed by a simple autoregressive model. Overall, our results indicate that economic agents' expectations formation process is suboptimal and/or the survey fails to capture the true inflation expectations.
\end{abstract}

JEL Classification: E52

Keywords: Survey data, Inflation targeting 



\section{Contents}

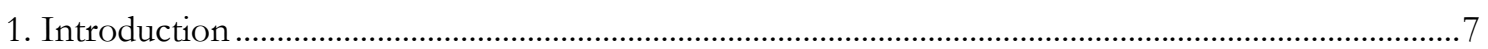

2. Data

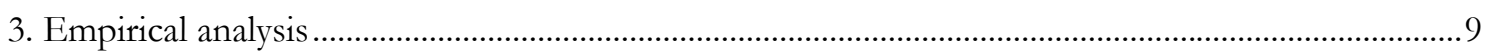

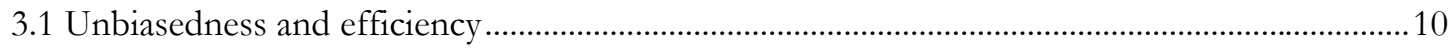

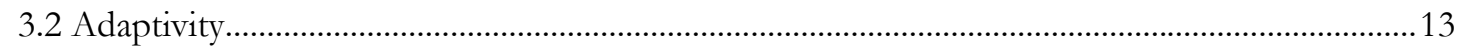

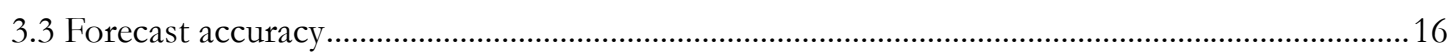

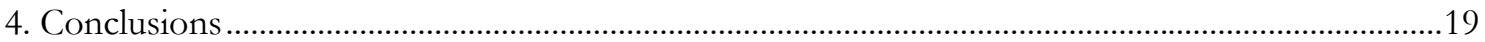

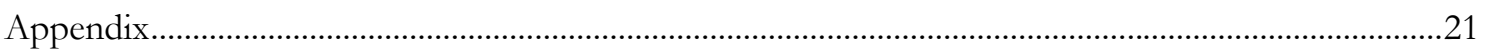





\section{Introduction}

After the Swedish fixed exchange rate regime was abandoned in November 1992, Sveriges Riksbank became one of the first central banks in the world to adopt inflation targeting. This policy regime has now been in place for more than fifteen years and has, in light of the relative stability the Swedish economy has enjoyed, broadly been judged a success.

The success of an inflation-targeting regime depends heavily on the inflation expectations of actors in the economy; inflation expectations that are well aligned with the inflation target facilitates achieving outcomes close to the target. However, even in an inflation-targeting regime, short-run inflation expectations should not be constant as the central bank cannot bring inflation back to its target immediately due to lags in the transmission mechanism. Moreover, in practice, no central bank practices what Svensson (2007) refers to as a "strict inflation targeting". ${ }^{1}$ Inflation will hence be brought back to the target more slowly than what would be the case if the central bank did not also care about output gap stability. This should of course be reflected in inflation expectations.

Sveriges Riksbank relies on survey-based measures of inflation expectations as part of its toolkit to gauge inflation expectations in Sweden. One of the more important survey-based measures is provided by the private company Prospera, on behalf of Sveriges Riksbank. Developments of the Prospera aggregates are generally cited in monetary policy reports. For example, in October 2009, the following was stated in the monetary policy report (Sveriges Riksbank, 2009):

"After having fallen over a period of one year, inflation expectations for one and two years' ahead rose slightly, according to Prospera's October survey. Looking one year ahead they are now 0.8 per cent, while at two years ahead the figure is 1.6 per cent. Inflation expectations five years ahead are at 2.2 per cent and are thus in line with the inflation target. Over the past decade they have at most been 0.5 percentage points off 2 per cent. This indicates that inflation expectations are firmly anchored. There are thus no signs that the recent very low inflation has reduced long-term inflation expectations significantly".

Because of their role as a key indicator of expected inflation, in this paper we assess the properties of inflation expectations as surveyed by Prospera. The behaviour of inflation expectations in other countries has been explored in several studies. ${ }^{2}$ This literature generally focus on two properties: The first of these is unbiasedness, that is, that inflation expectations are unbiased forecasts of future inflation. The second is efficiency, that is, that the expectations incorporate all available relevant in-

\footnotetext{
${ }^{1}$ Using the terminology coined by Mervyn King, no central bank is an "inflation nutter".

2 See, for example, Croushore (1997), Roberts (1997), Mehra (2002) and Mankiw et al. (2003). Thomas (1999) provides a survey of the literature.
} 
formation. The reason attention is paid to these properties is that violations can be interpreted as inconsistent with forecasters having rational expectations. In this paper we perform tests on the Prospera inflation expectations data under the inflation-targeting regime. Results suggest that the expectations are biased and, at the shortest horizons, not efficient. Our econometric analysis further suggests that long-run inflation expectations show excessive co-movement with actual inflation, a finding that raises questions regarding how the inflation expectations are formed. Finally, the predictive ability of inflation expectations surveyed by Prospera is contrasted with those of a professional forecasting institution and a simple autoregressive model. It is shown that the forecast precision of the survey-based inflation expectations tend to be lower than both alternatives. Overall, our results indicate that the survey fails to capture the true inflation expectations and/or the expectations formation process has shortcomings.

The remainder of this paper is organised as follows: Data are described in Section 2. In Section 3, the empirical analysis is conducted and the results are discussed. Section 4 concludes.

\section{Data}

Data on twelve-month-ended CPI inflation from 1996Q1 to 2009Q2 were provided by Statistics Sweden and are given in Figure 1. In the same figure, one-, two- and five-year ahead overall mean inflation expectations from Prospera are shown. Prospera conducts its survey on behalf of Sveriges Riksbank and provides the most ambitious survey concerning inflation expectations in Sweden. Prospera surveys 275 businesses and organisations once every quarter. The results of the survey are aggregated in an overall measure and into five subcategories: employee organisations, employer organisations, manufacturing companies, money market players and trade companies. Figures A1 to A3 in the Appendix show one-, two- and five-year mean inflation expectations by each subcategory. The inflation expectations are "forward rates" - that is, they measure twelve-month-ended inflation in 12,24 and 60 months time.

The data on inflation expectations consist of 55 observations per series and are approximately quarterly. While the survey is conducted four times per year, the interval is not fixed. We discuss this issue further below when relevant. 
Figure 1. CPI inflation and overall inflation expectations.

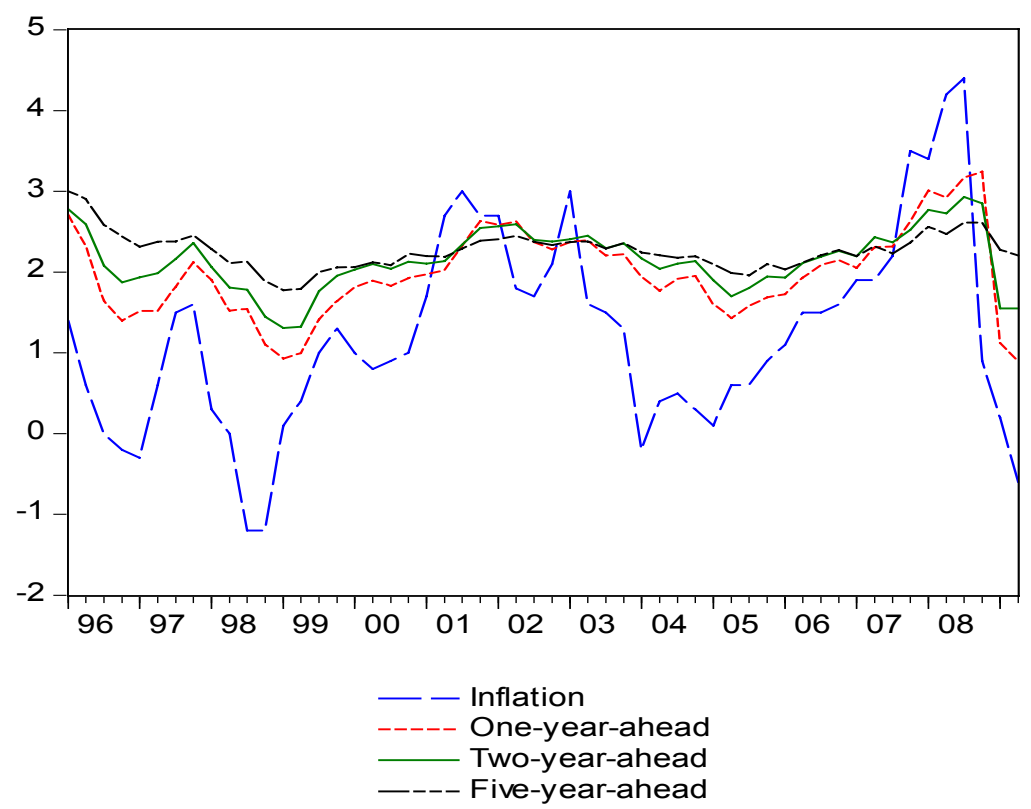

It can be seen from Figure 1 and Figures A1 to A3 that inflation expectations appear to vary over time with actual inflation and as would be expected, the expectations vary less the longer the horizon. But how much variation in expectations is reasonable at the different horizons surveyed here? The answer to this question is not obvious, but it can be noted that in a setting where the central bank's inflation target is credible - and where the central bank has a reasonably strong preference for stabilising inflation relative to the output gap - long-run inflation expectations should be very close to a constant; the five-year ahead expectations shown here can hardly be said to meet this criterion. Sveriges Riksbank (2007, p. 13) itself states that "monetary policy is normally focused on achieving the inflation target within two years". In line with this statement, inflation reports and monetary policy reports almost without exception forecast that inflation will be back at a level close to the target within two to three years. Given Sveriges Riksbank's clear statement of its inflation target and what appears to be a strong commitment to bring inflation back to this target reasonably fast, the fact that five-year ahead inflation expectations seem to move around with actual inflation is surprising. We next investigate the empirical properties of the survey-based inflation expectations to - among other things - see whether the observed amount of time variation found can be motivated.

\section{Empirical analysis}

Our empirical analysis of the survey-based inflation expectations are divided into three different parts. First, tests for unbiasedness and efficiency are conducted. Second, the degree of adaptivity of the expectations is investigated. It is common in the literature to find evidence for adaptive (rather 
than rational) inflation expectations and it is also a common modelling choice; see, for example, Phelps (1967), Roberts (1997), Rudebusch and Svensson (1999), Rudebusch (2002), Basdevant (2005). It hence seems reasonable to conduct such an exercise to provide further insight into potential shortcomings empirically of the expectations. Third, the predictive ability of the inflation expectations is contrasted with those of a professional forecasting institution and a simple autoregressive model. This comparison of forecast precision can be used to assess the properties of the expectations from another angle. For example, if the forecast precision of the expectations is substantially lower than that of the autoregressive model, one has to question how the expectations are formed (or measured) even if they have passed the tests for unbiasedness and efficiency.

\subsection{Unbiasedness and efficiency}

We employ a standard Mincer-Zarnowitz test (Mincer and Zarnowitz, 1969) for unbiasedness of expectations. This is based on the regression

$\pi_{t+h}=\alpha_{0}+\alpha_{1} \pi_{t+h \mid t}^{e}+\varepsilon_{t}$,

where $\pi_{t+h}$ is the twelve-month-ended inflation rate at date $t+h$ and $\pi_{t+h \mid t}^{e}$ represents a measure of the inflation rate expected at date $t+h$, conditional on information available at date $t$. If inflation expectations are unbiased forecasts of inflation, then $\alpha_{0}$ is zero and $\alpha_{1}$ is one. It can be noted that the residuals will exhibit serial correlation due to the overlapping nature of the data. This is taken into account by employing Newey-West standard errors.

Three hypotheses are tested. $H_{0}: \alpha_{0}=0$ and $H_{0}: \alpha_{1}=1$ are tested using $t$-tests and the joint hypothesis $H_{0}: \alpha_{0}=0, \alpha_{1}=1$ is tested using an $F$-test. Results are given in Table 1 . These show that for all time horizons and all groups - except the five-year ahead expectations of employers and the one- and five-year ahead expectations of money market players - the composite null hypothesis can be rejected at the five percent level. This result might not come as a complete surprise; the literature on survey expectations tends to find evidence against unbiasedness; see, for example, Croushore (1997), Roberts (1997), Thomas (1999), Mehra (2002) and. Mankiw et al. (2003). The finding of biased forecasts constitutes a violation of rational expectations under a symmetric quadratic loss function. Since we in practice never know the loss function of the forecasters, we do not make such a claim here but simply note that that this result should be considered a warning sign regarding the rationality of the formation of expectations. 
Table 1. Results from estimation of equation (1).

One-, two- and five-year ahead inflation expectations

\begin{tabular}{|c|c|c|c|c|c|}
\hline & $\hat{\alpha}_{0}$ & $\operatorname{se}\left(\hat{\alpha}_{0}\right)$ & $\hat{\alpha}_{1}$ & $\operatorname{se}\left(\hat{\alpha}_{1}\right)$ & $H_{0}: \alpha_{0}=0, \alpha_{1}=1$ \\
\hline \multicolumn{6}{|l|}{1 year } \\
\hline Overall & 0.89 & 0.84 & 0.22 & 0.45 & $3.19^{*}$ \\
\hline Employee & 1.10 & 0.78 & 0.11 & 0.42 & $3.64^{*}$ \\
\hline Employer & 0.91 & 0.71 & 0.21 & 0.40 & $3.22^{*}$ \\
\hline Manufacturing & 0.84 & 0.90 & 0.22 & 0.46 & $4.43^{*}$ \\
\hline Money market & 0.86 & 0.69 & 0.26 & 0.43 & 1.85 \\
\hline Trade & 0.95 & 0.90 & 0.18 & 0.47 & $3.73^{*}$ \\
\hline \multicolumn{6}{|l|}{2 years } \\
\hline Overall & $3.19^{* *}$ & 1.12 & -0.80 & 0.48 & $12.47^{* *}$ \\
\hline Employee & $3.70^{* *}$ & 1.02 & $-1.08^{* *}$ & 0.46 & $13.55^{* *}$ \\
\hline Employer & $2.50^{*}$ & 0.97 & -0.49 & 0.44 & $8.02^{* *}$ \\
\hline Manufacturing & 2.80 & 1.42 & -0.58 & 0.55 & $14.23^{* *}$ \\
\hline Money market & $3.47^{* *}$ & 1.16 & -1.01 & 0.61 & $5.77^{* *}$ \\
\hline Trade & 2.80 & 1.42 & -0.58 & 0.55 & $14.23^{* *}$ \\
\hline \multicolumn{6}{|l|}{5 years } \\
\hline Overall & -3.27 & 1.65 & 2.14 & 0.73 & $5.51^{* *}$ \\
\hline Employee & $-2.64^{*}$ & 1.20 & 1.87 & 0.55 & $7.23^{* *}$ \\
\hline Employer & -1.35 & 1.19 & 1.40 & 0.54 & 2.11 \\
\hline Manufacturing & $-3.59^{*}$ & 1.37 & 2.17 & 0.58 & $8.76^{* *}$ \\
\hline Money market & -3.06 & 1.84 & 2.20 & 0.85 & 2.87 \\
\hline Trade & -2.19 & 1.32 & 1.63 & 0.56 & $4.47^{*}$ \\
\hline
\end{tabular}

Note: ${ }^{* *}$ and ${ }^{*}$ indicate significance at the one and five percent level respectively. The null hypotheses tested for the individual coefficients are $H_{0}: \alpha_{0}=0$ and $H_{0}: \alpha_{1}=1$. Regressions have 51,46 and 34 observations at the one-, two- and five-year horizons.

We next turn to the issue of efficient use of macroeconomic data when forming inflation expectations. Standard macroeconomic models suggest that the unemployment rate should be useful when predicting future inflation. ${ }^{3}$ A parsimonious test of efficient use of data can therefore be based on the regression

$\pi_{t+h}-\pi_{t+h \mid t}=\beta_{0}+\beta_{1} u_{t-1}+\beta_{2} u_{t-2}+\beta_{3} u_{t-3}+\beta_{4} u_{t-4}+v_{t}$

where $u_{t-1}$ is the unemployment rate three months before time $t, u_{t-2}$ the unemployment rate six months before $t$ and so on. The null hypothesis $H_{0}: \beta_{1}=\beta_{2}=\beta_{3}=\beta_{4}=0$ is then tested using a standard F-test. The logic behind this test is simple: If variables that would be contained in a sophisticated model of inflation are significantly correlated with the forecast error, agents do not

\footnotetext{
3 The output gap is a variable of much importance in many models of inflation and it is related to the unemployiment rate according to Okun's law. In addition, the unemployment rate is commonly used in more atheoretical models addressing questions concerning inflation and monetary policy; see, for example, Cogley and Sargent (2001), Primiceri (2005) and Ribba (2006).
} 
make efficient use of information when forecasting. It should not be possible to improve forecasts using information available at time $t$.

Results are given in Table 2 and show that both the one- and two-year ahead inflation expectations do not sufficiently take into account the unemployment rate when formed. On the other hand, we find no significant effect of unemployment on the forecast errors of the five-year ahead inflation expectations. However, this insignificant effect at the longest horizon probably reflects the fact that the unemployment rate simply has no predictive power for inflation at very long horizons.

Table 2. Results from estimation of equation (2).

One-, two- and five-year ahead inflation expectations

\begin{tabular}{|c|c|}
\hline & $\mathbf{F}$ \\
\hline \multicolumn{2}{|l|}{1 year } \\
\hline Overall & $3.86^{* *}$ \\
\hline Employee & $3.71^{*}$ \\
\hline Employer & $3.47^{*}$ \\
\hline Manufacturing & $3.75^{*}$ \\
\hline Money market & $4.37^{* *}$ \\
\hline Trade & $3.71^{*}$ \\
\hline \multicolumn{2}{|l|}{2 years } \\
\hline Overall & $5.19^{* *}$ \\
\hline Employee & $5.30^{* *}$ \\
\hline Employer & $4.53^{* *}$ \\
\hline Manufacturing & $4.96^{* *}$ \\
\hline Money market & $6.00^{* *}$ \\
\hline Trade & $4.99^{* *}$ \\
\hline \multicolumn{2}{|l|}{5 years } \\
\hline Overall & 2.11 \\
\hline Employee & 1.96 \\
\hline Employer & 2.29 \\
\hline Manufacturing & 2.16 \\
\hline Money market & 2.12 \\
\hline Trade & 2.10 \\
\hline
\end{tabular}

Note: $F$ is the test statistic from the F-test of all slope coefficients in equation (2) being zero. ${ }^{* *}$ and ${ }^{*}$ indicate significance at the one and five percent level respectively. Regressions have 51, 46 and 34 observations at the onetwo- and five-year horizons.

The inefficient use of data at the shorter horizons found here is troublesome since it indicates empirical shortcomings of the expectations. This can have two reasons, which have different implications for policy makers who take them into account. First, the expectations formation process might be suboptimal. For example, inflation expectations might be formed in an adaptive rather than a rational way. This is an unwanted situation for the central bank since it makes it harder for it to achieve its goals. Second, it is possible that the survey is not capturing respondents' true inflation expectations. Survey-based measures of expectations are often criticised since the respondents have 
small incentives to give well thought answers; see, for example, Wolfers and Leigh (2002) and Gürkaynak and Wolfers (2005). Clearly, if true inflation expectations are not captured by the survey, they should not be given too much weight in the central bank's policy considerations. There is otherwise a risk that policy decisions are not based on the relevant information.

\subsection{Adaptivity}

Above we looked at unbiasedness and efficiency and established that the survey-based data studied here tend to lack both of these properties. If this is due to a suboptimal formation of expectations, one possible explanation for our findings is that the expectations are too heavily influenced by what has happened in the recent past. We therefore next investigate to what extent inflation expectations are adjusted with respect to actual data. This is done by running the regression

$\Delta \pi_{t+h \mid t}^{e}=\gamma_{0}+\gamma_{1} \Delta \pi_{t}^{L}+\xi_{t}$,

where $\Delta$ denotes the first difference operator and $\pi_{t}^{L}$ is the latest actual inflation figure available from official statistical sources when expectations are surveyed. ${ }^{4}$ For example, in late January, the latest available twelve-month-ended inflation rate is that of December (since Statistics Sweden releases this number in mid-January). The regressor in equation (3) will hence be the twelve-monthended inflation rate in December minus that in September.

The results are shown in Table 3. For all horizons and subcategories, the null of no co-movement between change in inflation and change in expectations is rejected. This suggests that there is a fair bit of co-movement in inflation expectations with actual inflation.

\footnotetext{
${ }^{4}$ Note that we run the regression using first differences rather than levels to avoid the inference problems associated with the use of stationary, but highly persistent, variables in levels. See, for example, Phillips (1987).
} 
Table 3. Results from estimation of equation (3).

One-, two- and five-year ahead inflation expectations

\begin{tabular}{|c|c|c|}
\hline & $\hat{\gamma}_{1}$ & $\operatorname{se}\left(\hat{\gamma}_{1}\right)$ \\
\hline \multicolumn{3}{|l|}{1 year } \\
\hline Overall & $0.31^{* *}$ & 0.06 \\
\hline Employee & $0.34^{* *}$ & 0.08 \\
\hline Employer & $0.35^{* *}$ & 0.08 \\
\hline Manufacturing & $0.34^{* *}$ & 0.06 \\
\hline Money market & $0.26^{* *}$ & 0.06 \\
\hline Trade & $0.31^{* *}$ & 0.07 \\
\hline \multicolumn{3}{|l|}{2 years } \\
\hline Overall & $0.19^{* *}$ & 0.04 \\
\hline Employee & $0.22^{* *}$ & 0.06 \\
\hline Employer & $0.21^{* *}$ & 0.06 \\
\hline Manufacturing & $0.23^{* *}$ & 0.04 \\
\hline Money market & $0.10^{* *}$ & 0.03 \\
\hline Trade & $0.19^{* *}$ & 0.04 \\
\hline \multicolumn{3}{|l|}{5 years } \\
\hline Overall & $0.09^{* *}$ & 0.02 \\
\hline Employee & $0.12^{* *}$ & 0.02 \\
\hline Employer & $0.11^{* *}$ & 0.03 \\
\hline Manufacturing & $0.11^{* *}$ & 0.02 \\
\hline Money market & $0.05^{* *}$ & 0.02 \\
\hline Trade & $0.10^{* *}$ & 0.02 \\
\hline
\end{tabular}

Note: ${ }^{* *}$ and ${ }^{*}$ indicate significance at the one and five percent level respectively.

Adaptivity does not necessarily mean that survey participants are irrational though. If inflation is persistent, it makes sense to revise forecasts in line with the shocks that arrive. In order to investigate whether the extent of the revisions in expectations is motivated by the inflation data, we specify an autoregressive model for actual inflation, where the AR(1) model:

$\pi_{t}=\delta_{0}+\delta_{1} \pi_{t-1}+\chi_{t}$

appears to be the best representation according to the Schwarz (1978) information criterion. ${ }^{5}$ Based on the AR(1) model, we can compare the estimated persistence of the inflation data to the implied persistence based on the regressions in equation (4). The estimated persistence of the AR(1) model is given by the estimate of $\delta_{1}$ in equation (4). Implied persistence for the model in equation (3) is calculated as $P=\exp \left(\ln \left(\hat{\gamma}_{1}\right) / h\right)$, where $h$ is the horizon of the expectation in quarters. To see the intuition behind this calculation, first recall that the impulse response at horizon $b$ for the $\operatorname{AR}(1)$ model is given by $\left(\delta_{1}\right)^{h}$. It can then be noted that the coefficient $\gamma_{1}$ is similar to an impulse re-

\footnotetext{
${ }^{5}$ The AR(1) model is estimated using data from 1996Q1 to 2009Q2. The data employed are from February, May, August and November each year since this is the timing which best approximates the slightly irregular dates of the survey.
} 
sponse since it tells us how much the inflation expectation is revised in the light of a shock. ${ }^{6}$ Similarly, we can compare the half life based on the AR(1) model to the implied half life. The half life for the $\operatorname{AR}(1)$ process, $H^{\delta}$, is calculated as $H^{\delta}=\ln (0.5) / \ln \left(\hat{\delta}_{1}\right)$ and the half life for the model in equation (3), $H^{\gamma}$, is given by $H^{\gamma}=\ln (0,5) / \ln (P)$. Results are found in Table 4 and first of all it can be noted that the AR(1) model estimates persistence to be 0.81 . This means that the estimated half life of inflation is 3.2 quarters. As can be seen from Table 4, the implied half-lives for one-year horizon expectations are in line with that or even shorter. For the two-year horizon, the half life is also largely in line with what was estimated in the AR(1)-model, albeit generally somewhat higher (save for the money market players). This can be interpreted as the respondents having a degree of adaptivity at the shorter horizons which is consistent with the persistence that can be found in the data.

For the five-year horizon, however, the implied half life is substantially higher (1.5 to 3.6 quarters), than what was found in the data. This result suggests that the survey participants on average, when making their forecasts at the five year horizon and when observing changes in actual inflation, overestimate the persistence of the shock to the inflation rate.

Needless to say, the survey participants are unlikely to use a simple AR(1) model to forecast. However, the above analysis suggests that if they were, they would be using different estimates of persistence at the different horizons. That is obviously a peculiar feature and yet another cause for concern regarding the survey data.

The results in this subsection indicate that the time variation in one- and two-year ahead expectations is reasonable given the data. However, the same cannot be said about five-year ahead expectations. As an example, employee organisations revise the five-year ahead inflation expectation with 12 basis points when actual inflation changes by 100 basis points. Based on the persistence in the data - which according to the AR(1) model is 0.81 - a forecast should only be revised by one basis point in light of a 100 basis point shock. Rather than the fairly substantial variation in the five-yearahead expectations shown in Figure A3, one would expect these to be close to constant if they were to be consistent with the persistence in the data.

\footnotetext{
${ }^{6}$ It should be noted that using the change in inflation as the shock is an approximation to the true shock. However, using an $A R(1)$ model - with a range of reasonable values of the autoregressive parameter - shows that our results are not sensitive to this assumption. The estimates of $\gamma_{1}$ are very similar in those cases. Results are not reported but are available upon request.
} 
Table 4. Persistence and half life based on equation (4). Implied persistence and implied half life based on equation ( 3 ).

Actual inflation and one-, two- and five-year ahead inflation expectations

Persistence $\begin{gathered}\text { Implied per- Half-life Implied half- } \\ \text { sistence }\end{gathered}$

Inflation

0.81

3.2

\begin{tabular}{lll}
\hline year & & \\
Overall & 0.79 & 2.9 \\
\hline Employee & 0.81 & 3.2 \\
Employer & 0.81 & 3.3 \\
\hline Manufacturing & 0.81 & 3.2 \\
\hline Money market & 0.76 & 2.5 \\
\hline Trade & 0.79 & 2.9 \\
\hline 2 years & & \\
\hline Overall & & 3.7 \\
\hline Employee & 0.83 & 4.1 \\
\hline Employer & 0.84 & 4.0 \\
\hline Manufacturing & 0.84 & 4.3 \\
\hline Money market & 0.85 & 2.7 \\
\hline Trade & 0.77 & 3.7 \\
\hline & 0.83 & \\
\hline years & & 6.1 \\
\hline Overall & & 6.8 \\
\hline Employee & 0.89 & 6.6 \\
\hline Employer & 0.90 & 6.6 \\
\hline Manufacturing & 0.90 & 4.7 \\
\hline Money market & 0.90 & 6.2 \\
\hline Trade & 0.86 & \\
\hline & 0.89 & \\
\hline
\end{tabular}

\subsection{Forecast accuracy}

Our results so far show that the inflation expectations surveyed by Prospera tend to be biased and do not make efficient use of available macroeconomic data. It is also shown that the five-year-ahead expectations are overly adaptive. All of these findings could be interpreted as a lack of rationality in the expectation formation process. As the final stage in the assessment of the inflation expectations, we turn to the issue of forecast accuracy. This is done by comparing the forecasting performance of the Prospera respondents with that of other forecasters.

To begin with, we compare the forecast performance of the Prospera survey participants with that of the National Institute of Economic Research (NIER), a government agency making forecasts of the inflation rate in Sweden among other economic variables. Due to the real-time database available and the forecast horizon of the NIER, we are only able to compare the root mean square forecast errors (RMSFEs) at the one-year horizon for forecasts surveyed by Prospera between April 
2001 and June 2008. The NIERs forecast is the official forecast made closest in time before the Prospera survey was conducted; this means that the NIER has an informational disadvantage of a touch less than two months on average. Results are shown in Table 5 and show that despite the informational disadvantage of the NIER, it has the lowest RMSFE.7

Table 5. RMSFEs from different forecasts.

\section{One year}

\begin{tabular}{ll} 
NIER & 1.28 \\
Overall & 1.53 \\
Employee & 1.53 \\
Employer & 1.53 \\
Manufacturing & 1.63 \\
Money market & 1.39 \\
Trade & 1.56 \\
\hline
\end{tabular}

Note: RMSFEs are based on forecasts surveyed by Prospera from April 2001 to June 2008 and the matching forecasts from the National Institute of Economic Research. This means that 30 one-year-ahead forecasts are evaluated.

That the NIER outperforms the Prospera survey participants is perhaps not completely surprising. As was shown by Andersson and Aranki (2009), the NIER is one of the best forecasters of inflation in Sweden. Having initially chosen a benchmark that might be very hard to beat, we next turn to a comparison in which it should be easier for the expectations to come out on top, namely a purely model-based forecast. The model in question is a Bayesian $\mathrm{AR}(1)$ model which allows us to take the inflation target of Sveriges Riksbank into account; see Villani (2009) for technical details. The model is given by

$\pi_{t}-\mu=\rho\left(\pi_{t-1}-\mu\right)+\zeta_{t}$

where $\mu$ is the steady state of the process. The prior for the steady-state rate of inflation is here given by a normal distribution with mean of 2 percent and where a 95 percent prior interval is given by $(1.5,2.5)$. From a forecasting point of view, the AR(1) model in equation (5) is highly likely to be a better tool than that of equation (4) since it provides a means to let institutional knowledge about the inflation target affect the level at which forecasts converge. ${ }^{8}$ We hence believe that it is a reasonable model on which to base the comparison to the survey-based expectations.

\footnotetext{
7 The difference in forecasting performance is also significant at the five percent level against emloyeee organisations and manufacturing companies if a Diebold-Mariano test (Diebold and Mariano, 1995) assuming quadratic loss is conducted; results are not reported but are available upon request. Given the poor power of this test in small samples - see, for example, Hjalmarsson (2006) - this indicates that the difference in forecasting performance is substantial.

${ }^{8}$ For empirical evidence concerning the benefits of this specification over the more traditional alternative, see Beechey and Österholm (2009a).
} 
The data used for the out-of-sample forecast exercise are quarterly and, just like when persistence was estimated in Section 3.2, the February, May, August and November values each year are employed. When evaluating the expectations data, we compare the expectations of the first Prospera survey each year to the inflation rate in February the next year, the expectations from the second survey each year to the inflation rate in May the next year and so on. This means, since the survey is not conducted the same month each year, that we introduce a timing approximation error of roughly half a month on average. Comparisons to the $\mathrm{AR}(1)$ model using these data nevertheless should be informative since the approximation error is very small; at the longer horizons, it is negligible.

The out-of-sample forecast comparison is based on forecasts surveyed by Prospera from November 1999 to June 2008. This means that 35, 31 and 19 forecasts for the one-, two- and five-year horizons are evaluated. The model-based forecasts are generated using an expanding sample. The first forecast is generated using data from February 1996 to August 1999 and forecasts up to 21 periods ahead are generated. Forecasts for five, nine and twenty one quarters ahead are recorded and the associated forecast errors calculated. ${ }^{9}$ One quarter is then added to the sample, new forecasts generated and so on until the sample consists of data from February 1996 to February 2008 (where only the five-quarter-ahead forecast can be evaluated against data). ${ }^{10}$

Results from this out-of-sample exercise are found in Table 6. The AR(1) model performs best of all when evaluating the five-year horizon. At the two shorter horizons, it generates the second best forecast; money-market players are marginally better. Admittedly the number of observations is low, particularly at the five-year horizon, but these results serve as a clear indication that the survey expectations have problems. The AR(1) model is extremely simple and relies only on lagged inflation as data input. Categories other than money-market players should reasonably be expected to outperform the forecasts from this model, at least at the two shorter horizons.

\footnotetext{
9 Note that in real time, data on inflation in November is not available until mid-December and standing in November, we accordingly have to rely on data only up until August for the forecast. We therefore have to forecast five, nine and twenty one quarters ahead in order to get the relevant forecasts.

${ }^{10}$ Estimating the model in equation (5) on the full sample, we get a posterior median estimate of 0.81 of the persistence; the estimate of the unconditional mean is 1.83. Using only the first half of the sample, that is, $1996 \mathrm{Q} 1$ and $2002 \mathrm{Q} 3$, we get 1.89 for the unconditional mean and 0.83 for the persistence. Hence, high persistence early on in the sample does not seem to be a rationale for high implicit persistence of the five-year-ahead survey data. (High persistence early on in the sample is not an unreasonable suspicion since Sveriges Riksbank perhaps lacked credibility in the early days of inflation targeting due to its previous lack of commitment to the fixed exchange rate regime.)
} 
Table 6. RMSFEs from different forecasts.

\begin{tabular}{lccc} 
& One year & Two years & Five years \\
AR(1) & 1.21 & 1.30 & 1.21 \\
& & & \\
Overall & 1.27 & 1.42 & 1.34 \\
Employee & 1.29 & 1.41 & 1.30 \\
Employer & 1.27 & 1.39 & 1.27 \\
Manufacturing & 1.29 & 1.44 & 1.39 \\
Money market & 1.18 & 1.28 & 1.27 \\
\hline Trade & 1.36 & 1.53 & 1.43 \\
\hline
\end{tabular}

Note: RMSFEs are based on forecasts surveyed by Prospera from November 1999 to June 2008. This means that 35,31 and 19 forecasts for the one-, two- and five-year horizons are evaluated.

\section{Conclusions}

In this paper, we have shown that inflation expectations in Sweden, as surveyed by Prospera, are neither unbiased nor efficient forecasts of inflation. Expectations at all horizons also show a fair degree of adaptivity. Evaluating out-of-sample forecasting performance, we find that participants in the Prospera survey generally perform worse than a professional forecasting institution and a simple autoregressive model. The exact causes of these features are unclear but we suggest two main explanations.

First, biased and inefficient expectations are generally considered to be a violation of rational expectations and we believe that these findings do indeed indicate that the expectations formation process might be suboptimal. It is true that biased forecasts still can be rational, for example if the forecasters have asymmetric loss functions; see Elliott et al. (2008). It is, however, hard to justify inefficient use of macroeconomic data. In addition, the time variation seen in five-year-ahead expectations is excessive. Rational arguments for a fair amount of variabiltity in long-run inflation expectations exist. For example, if the central bank's inflation target is not credible - or if the central bank has a very strong preference for stabilising the real economy relative to inflation - one would expect rational agents to revise their long-run expectations in line with shocks to actual inflation.11, ${ }^{12}$ Given the communication of Sveriges Riksbank, where there always has been a clear focus on achieving the target within two to three years, such explanations seem farfetched though. Moreover, the very high persistence that such explanations imply is not present in the actual inflation data.

\footnotetext{
11 A moving inflation target is fairly common in the literature; see, for example, Beechey (2004) and Kozicki and Tinsley (2005). One could, for example, imagine that Sveriges Riksbank has an inflation target which can move as a random walk within the tolerance interval of \pm 1 percent around the target of 2 percent. However, such a bounded random walk for the target seems to be a more reasonable description of the Reserve Bank of Australia, with its substantially more flexible description of its target, or the Federal Reserve, with its implicit inflation target, than Sveriges Riksbank.

12 Clarida et al. (1999) show, using a standard model, that inflation persistence is a function of the relative preference for output stability. If this preference is strong, inflation may deviate from its target for extended periods. For a further discussion of this issue, see Beechey and Österholm (2007,2009b).
} 
Second, the recorded inflation expectations might not be the respondents' true inflation expectations. Criticism of survey-based measures of expectations is common and obviously applies also here. For example, no money is at stake in this survey and incentives to give well thought answers are hence low. It is therefore not unreasonable that the survey provides an imperfect measure of true expectations. Unfortunately, alternative indicators of inflation expectations are not flawless either, a fact which was made painfully clear during the recent financial crisis when, for example, flight-to-quality made the market-based break-even inflation rate a more or less useless measure of inflation expectations. So while survey-based inflation expectations might have shortcomings, we may still want to use them.

Our empirical analysis does not enable us to conclude whether the expectations process is suboptimal or the expectations mismeasured; the poor forecasting performance established above, for example, would be expected in both cases. In our opinion, it is not unlikely that both of these issues apply. Knowing the extent of the two would of course be interesting, particularly since they have different implications for the policy maker. Woodford (2004) describes central banking as the "management of expectations" and an expectations formation process that is flawed is not beneficial for the conduct of monetary policy. The policy rate may, for example, have to be varied more in order to stabilise the economy than would have been the case if expectations had been rational. If, on the other hand, true inflation expectations are not captured by the survey, policymakers should make sure to treat them as a noisy signal of true inflation expectations so that they are not mislead in the decision process. Assessing the relative importance of a suboptimal expectations formation process and mismeasurement of expectations is an important next step for future research. 


\section{Appendix}

Figure A1. One-year-ahead inflation expectations.

Overall

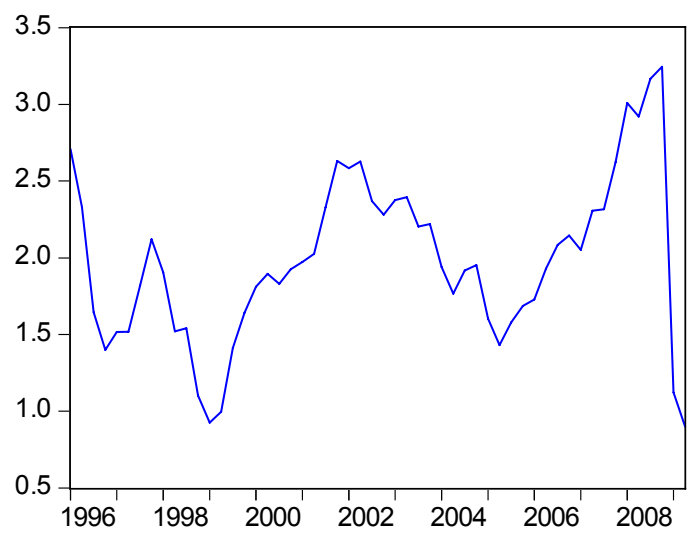

Employer

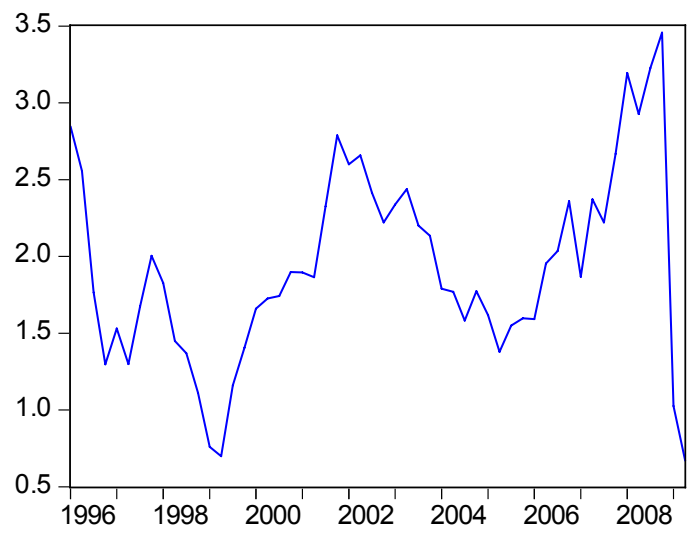

Money market

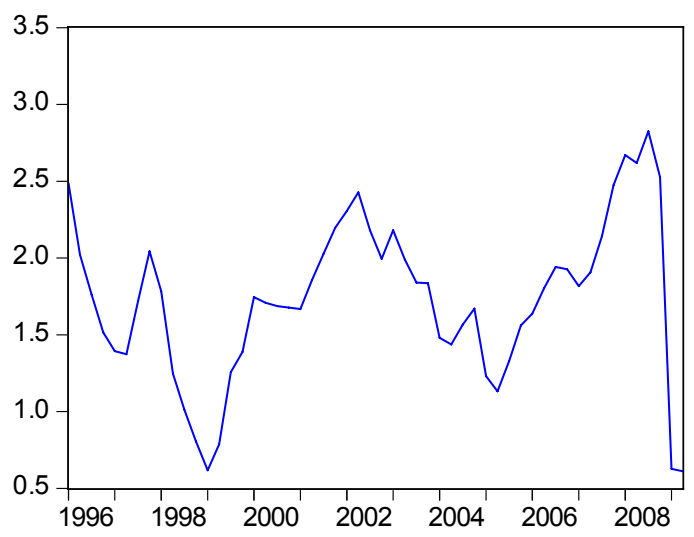

Employee

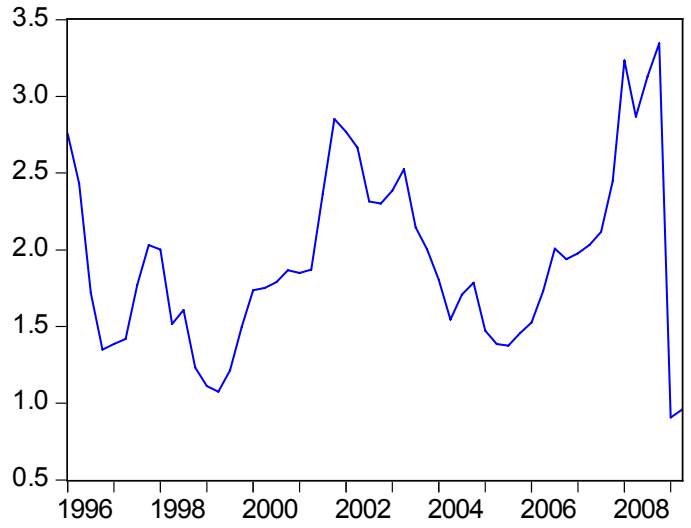

Manufacturing

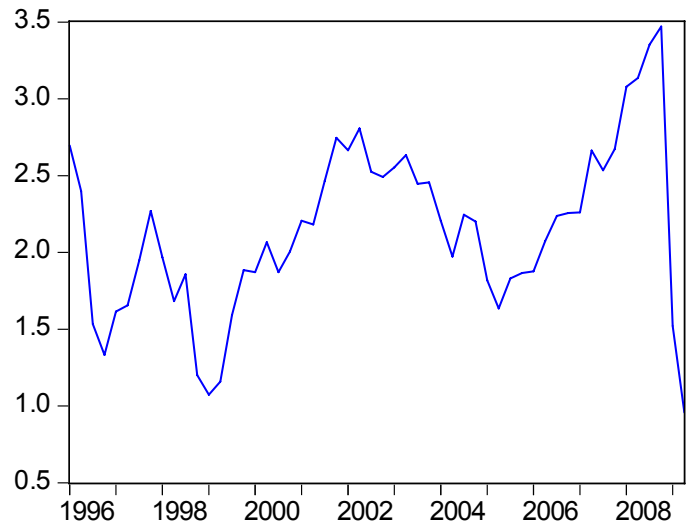

Trade

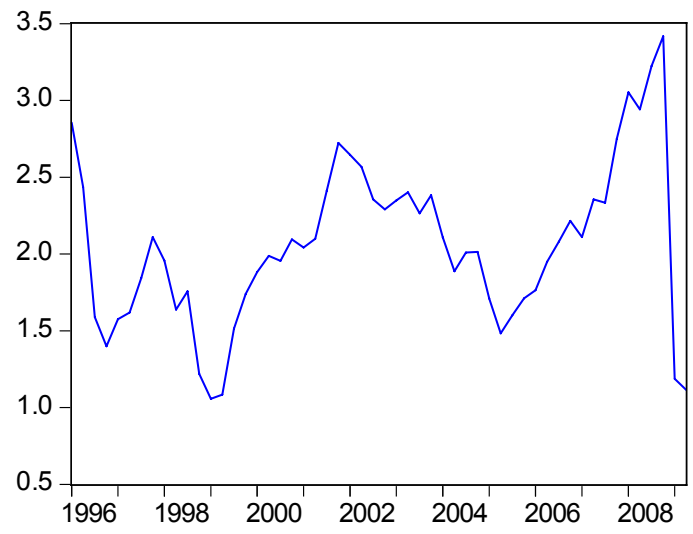


Figure A2. Two-year-ahead inflation expectations.

Overall

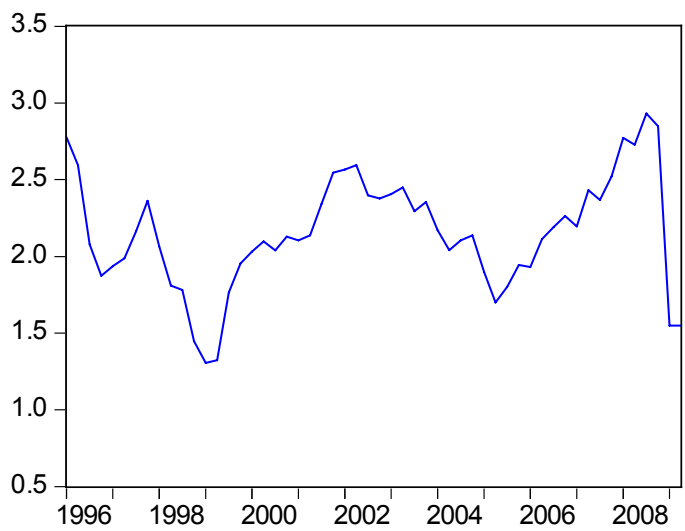

Employer

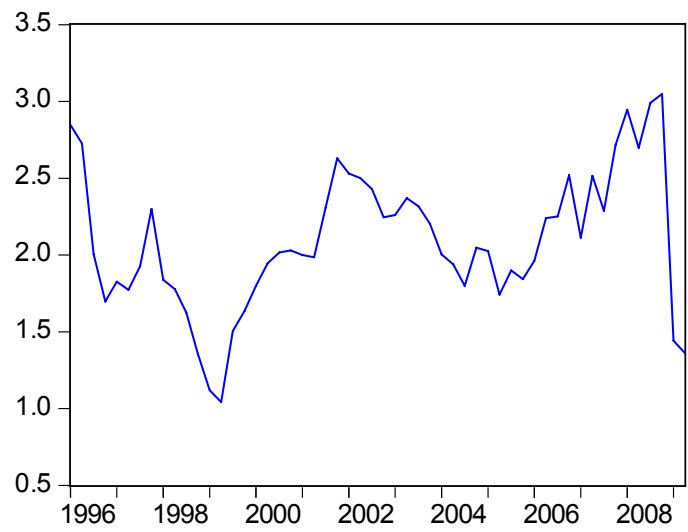

Money market

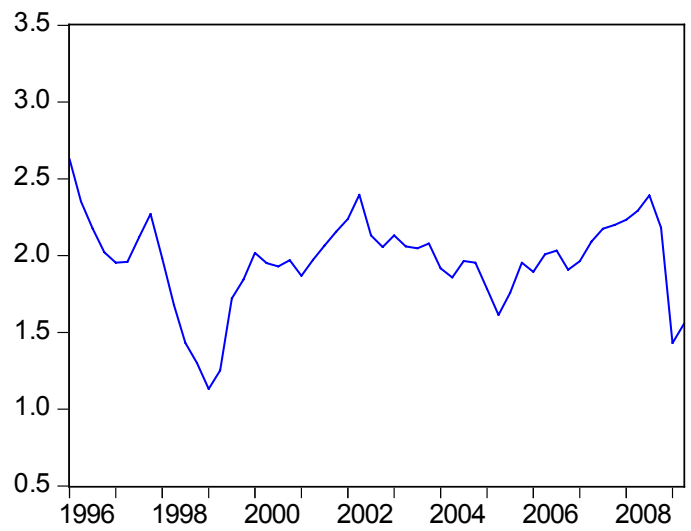

Employee

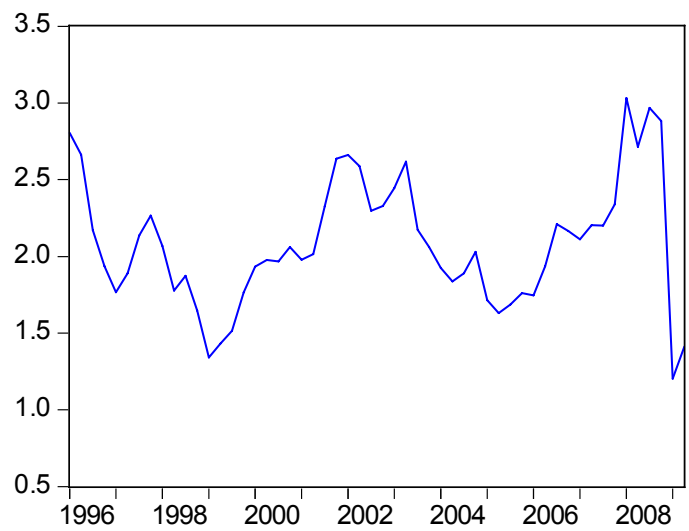

Manufacturing

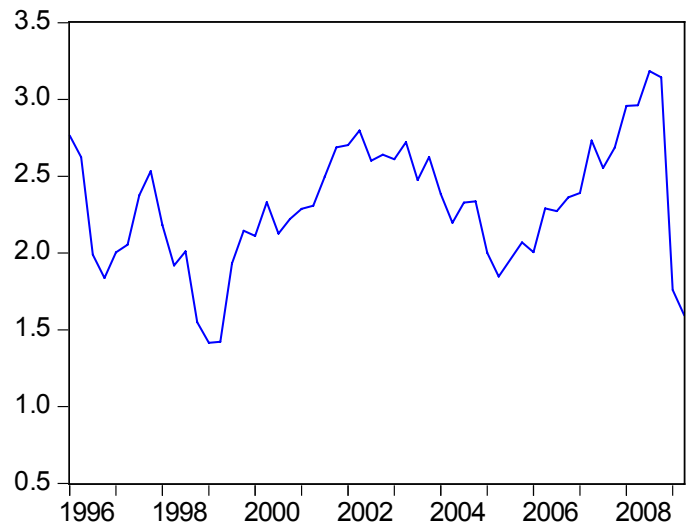

Trade

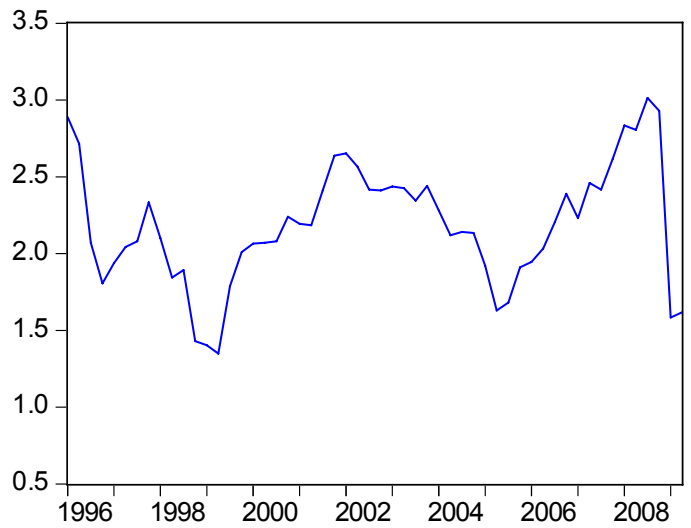


Figure A3. Five-year-ahead inflation expectations.

Overall

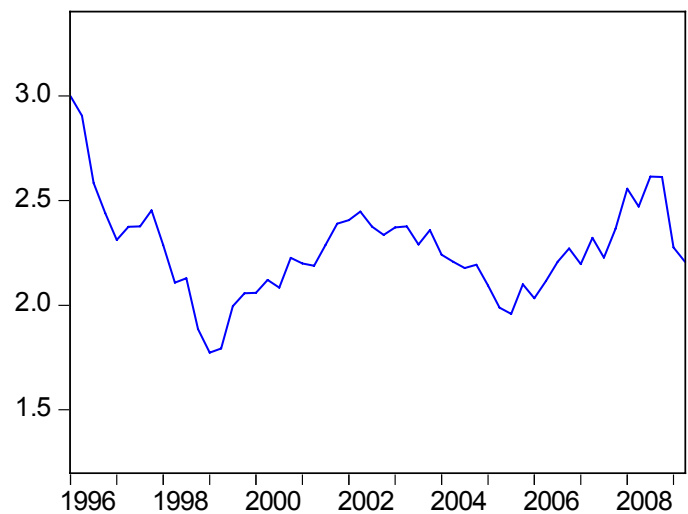

Employer

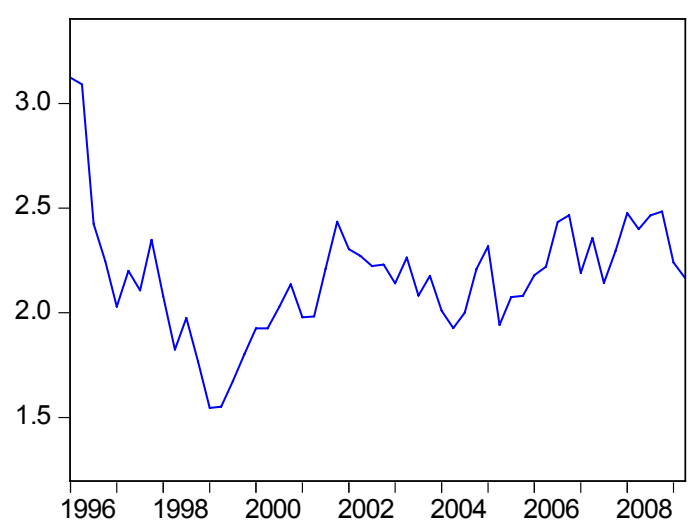

Money market

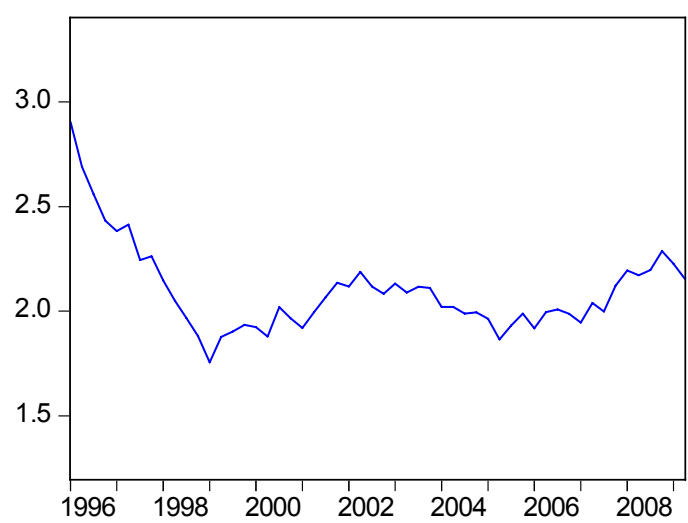

Employee



Manufacturing
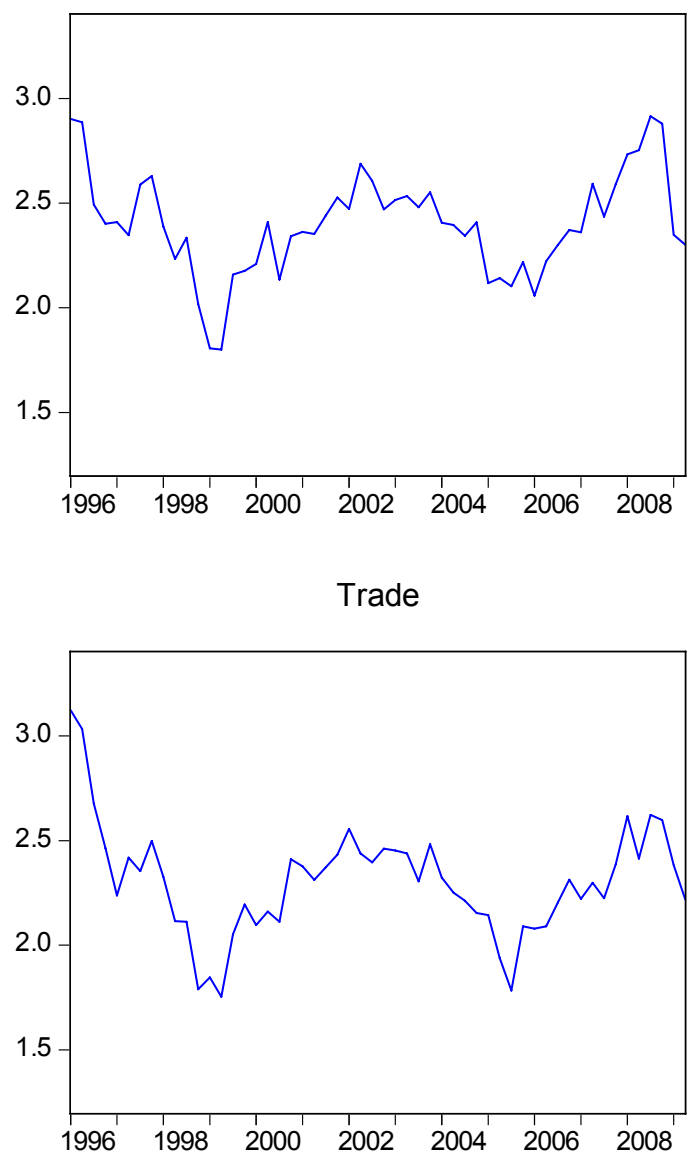


\section{References}

Andersson, M. K. and Aranki, T. (2009), "Forecasters' Ability - What Do We Usually Assess and What Would We Like to Assess?”, Sveriges Riksbank Economic Review 3/2009, 26-51.

Basdevant, O. (2005), "Learning Process and Rational Expectations: An Analysis Using a Small Macro-Economic Model for New Zealand”, Economic Modelling 22, 1074-1089.

Beechey, M. (2004), "Excess Sensitivity and Volatility of Long Interest Rates: The Role of Limited Information in Bond Markets", Working Paper No. 173, Sveriges Riksbank.

Beechey, M. and Österholm, P. (2007), "The Rise and Fall of US Inflation Persistence", Finance and Economics Discussion Series 2007-26, Board of Governors of the Federal Reserve System.

Beechey, M. and Österholm, P. (2009a), "Forecasting Inflation in an Inflation Targeting Regime: A Role for Informative Steady-State Priors", Forthcoming in International Journal of Forecasting.

Beechey, M. and Österholm, P. (2009b), "Time-Varying Inflation Persistence in the Euro Area", Economic Modelling 26, 532-535.

Clarida, R., Galí, J. and Gertler, M. (1999), “The Science of Monetary Policy: A New Keynesian Perspective", Journal of Economic Literature 37, 1661-1707.

Cogley, T. and Sargent, T. J. (2001), "Evolving Post-World War II U.S. Inflation Dynamics", NBER Macroeconomics Annual 16, 331-373.

Croushore, D. (1997), “The Livingstone Survey: Still Useful after All These Years”, Federal Reserve Bank of Philadelphia Business Review, 1-12.

Diebold F. X. and Mariano R. S. (1995), "Comparing Predictive Accuracy"., Journal of Business and Economic Statistics 13, 253-263.

Elliott, G., Komunjer, I. and Timmermann, A. (2008), "Biases in Macroeconomic Forecasts: Irrationality or Asymmetric Loss?”, Journal of the European Economic Association 6, 122-157

Gürkaynak, R. and Wolfers, J. (2005), "Macroeconomic Derivatives: An Initial Analysis of MarketBased Macro Forecasts, Uncertainty and Risk", In: Frankel, J. and Pissarides, C. (eds), NBER International Seminar on Macroeconomics, MIT Press, Boston.

Hjalmarsson E. (2006), "Should We Expect Significant Out-of-Sample Results when Predicting Stock Returns?", International Finance Discussion Papers No. 855, Board of Governors of the Federal Reserve System.

Kozicki, S. and Tinsley, P. A. (2005), "Permanent and Transitory Policy Shocks in an Empirical Macro Model with Asymmetric Information", Journal of Economic Dynamics and Control 29, 1985-2015. 
Mankiw, N. G., Reis, R., Wolfers, J. (2003), “Disagreements about Inflation Expectations”, NBER Macroeconomics Annual 18, 209-248.

Mehra, Y. P. (2002), "Survey Measures of Expected Inflation: Revisiting the Issues of Predictive Content and Rationality", Federal Reserve Bank of Richmond Quarterly Review 88, 17-36.

Mincer, J. and Zarnowitz, V. (1969). "The Evaluation of Economic Forecasts" in Mincer, J. (ed), Economic Forecasts and Expectations, NBER, New York .

Phelps, E. S. (1967), "Phillips Curves, Expectations of Inflation and Optimal Unemployment Over Time", Economica 34, 254-281.

Phillips, P. C. B. (1987), “Towards a Unified Asymptotic Theory for Autoregression”, Biometrika 74, 535-547.

Primiceri, G. (2005), “Time Varying Structural Vector Autoregressions and Monetary Policy", Review of Economic Studies, 72, 821-852.

Ribba, A. (2006), "The Joint Dynamics of Inflation, Unemployment and Interest Rate in the United States Since 1980", Empirical Economics 31, 497-511.

Roberts, J. M. (1997), “Is Inflation Sticky?”, Journal of Monetary Economics 39, 176-196.

Rudebusch, G. D. (2002), “Assessing Nominal Income Rules for Monetary Policy with Models and Data Uncertainty”, Economic Journal 112, 402-432.

Rudebusch, G. D. and Svensson, L. E. O. (1999), "Policy Rules for Inflation Targeting”, In: Taylor, J. B. (ed), Monetary Policy Rules, University of Chicago Press, Chicago.

Schwarz, G. (1978), "Estimating the Dimension of a Model”, Annals of Statistics 6, 461-464.

Svensson, L. E. O. (2007), "Inflation Targeting", In: Blum, L. and Durlauf, S. (eds), The New Palgrave Dictionary of Economics, Second Edition, Palgrave Macmillan, New York.

Sveriges Riksbank (2007), Monetary Policy in Sweden.

Sveriges Riksbank (2009), Monetary Policy Report, October 2009.

Thomas, L. B., (1999) "Survey Measures of Expected U.S. Inflation", Journal of Economic Perspectives $13,125-144$.

Villani, M. (2009), "Steady State Priors for Vector Autogregressions", Journal of Applied Econometrics 24, 630-650.

Wolfers, J. and Leigh, A. (2002), "Three Tools for Forecasting Federal Elections: Lessons from 2001”, Australian Journal of Political Science 37, 223-240.

Woodford, M. (2004), "Inflation Targeting and Optimal Monetary Policy", Federal Reserve Bank of St. Louis Economic Review 86, 15-41 


\section{Titles in the Working Paper Series}

\begin{tabular}{|c|c|c|c|}
\hline No & Author & Title & Year \\
\hline 1 & $\begin{array}{l}\text { Warne, Anders and } \\
\text { Anders Vredin }\end{array}$ & $\begin{array}{l}\text { Current Account and Business Cycles: Stylized Facts } \\
\text { for Sweden }\end{array}$ & 1989 \\
\hline 2 & Östblom, Göran & $\begin{array}{l}\text { Change in Technical Structure of the Swedish Econ- } \\
\text { omy }\end{array}$ & 1989 \\
\hline 3 & Söderling, Paul & $\begin{array}{l}\text { Mamtax. A Dynamic CGE Model for Tax Reform } \\
\text { Simulations }\end{array}$ & 1989 \\
\hline 4 & $\begin{array}{l}\text { Kanis, Alfred and Alek- } \\
\text { sander Markowski }\end{array}$ & $\begin{array}{l}\text { The Supply Side of the Econometric Model of the } \\
\text { NIER }\end{array}$ & 1990 \\
\hline 5 & Berg, Lennart & The Financial Sector in the SNEPQ Model & 1991 \\
\hline 6 & $\begin{array}{l}\text { Ågren, Anders and Bo } \\
\text { Jonsson }\end{array}$ & $\begin{array}{l}\text { Consumer Attitudes, Buying Intentions and Con- } \\
\text { sumption Expenditures. An Analysis of the Swedish } \\
\text { Household Survey Data }\end{array}$ & 1991 \\
\hline 7 & $\begin{array}{l}\text { Berg, Lennart and } \\
\text { Reinhold Bergström }\end{array}$ & $\begin{array}{l}\text { A Quarterly Consumption Function for Sweden } \\
\text { 1979-1989 }\end{array}$ & 1991 \\
\hline 8 & Öller, Lars-Erik & $\begin{array}{l}\text { Good Business Cycle Forecasts- A Must for Stabili- } \\
\text { zation Policies }\end{array}$ & 1992 \\
\hline 9 & $\begin{array}{l}\text { Jonsson, Bo and Anders } \\
\text { Ågren }\end{array}$ & $\begin{array}{l}\text { Forecasting Car Expenditures Using Household } \\
\text { Survey Data }\end{array}$ & 1992 \\
\hline 10 & $\begin{array}{l}\text { Löfgren, Karl-Gustaf, } \\
\text { Bo Ranneby and Sara } \\
\text { Sjöstedt }\end{array}$ & $\begin{array}{l}\text { Forecasting the Business Cycle Not Using Minimum } \\
\text { Autocorrelation Factors }\end{array}$ & 1992 \\
\hline 11 & Gerlach, Stefan & $\begin{array}{l}\text { Current Quarter Forecasts of Swedish GNP Using } \\
\text { Monthly Variables }\end{array}$ & 1992 \\
\hline 12 & Bergström, Reinhold & $\begin{array}{l}\text { The Relationship Between Manufacturing Produc- } \\
\text { tion and Different Business Survey Series in Sweden }\end{array}$ & 1992 \\
\hline 13 & $\begin{array}{l}\text { Edlund, Per-Olov and } \\
\text { Sune Karlsson }\end{array}$ & $\begin{array}{l}\text { Forecasting the Swedish Unemployment Rate: VAR } \\
\text { vs. Transfer Function Modelling }\end{array}$ & 1992 \\
\hline 14 & $\begin{array}{l}\text { Rahiala, Markku and } \\
\text { Timo Teräsvirta }\end{array}$ & $\begin{array}{l}\text { Business Survey Data in Forecasting the Output of } \\
\text { Swedish and Finnish Metal and Engineering Indus- } \\
\text { tries: A Kalman Filter Approach }\end{array}$ & 1992 \\
\hline 15 & $\begin{array}{l}\text { Christofferson, Anders, } \\
\text { Roland Roberts and } \\
\text { Ulla Eriksson }\end{array}$ & $\begin{array}{l}\text { The Relationship Between Manufacturing and Vari- } \\
\text { ous BTS Series in Sweden Illuminated by Frequency } \\
\text { and Complex Demodulate Methods }\end{array}$ & 1992 \\
\hline 16 & Jonsson, Bo & $\begin{array}{l}\text { Sample Based Proportions as Values on an Inde- } \\
\text { pendent Variable in a Regression Model }\end{array}$ & 1992 \\
\hline 17 & Öller, Lars-Erik & $\begin{array}{l}\text { Eliciting Turning Point Warnings from Business } \\
\text { Surveys }\end{array}$ & 1992 \\
\hline 18 & Forster, Margaret M & $\begin{array}{l}\text { Volatility, Trading Mechanisms and International } \\
\text { Cross-Listing }\end{array}$ & 1992 \\
\hline 19 & Jonsson, Bo & $\begin{array}{l}\text { Prediction with a Linear Regression Model and Er- } \\
\text { rors in a Regressor }\end{array}$ & 1992 \\
\hline 20 & $\begin{array}{l}\text { Gorton, Gary and Rich- } \\
\text { ard Rosen }\end{array}$ & $\begin{array}{l}\text { Corporate Control, Portfolio Choice, and the De- } \\
\text { cline of Banking }\end{array}$ & 1993 \\
\hline 21 & $\begin{array}{l}\text { Gustafsson, Claes- } \\
\text { Håkan and Åke Holmén }\end{array}$ & $\begin{array}{l}\text { The Index of Industrial Production - A Formal } \\
\text { Description of the Process Behind it }\end{array}$ & 1993 \\
\hline 22 & Karlsson, Tohmas & $\begin{array}{l}\text { A General Equilibrium Analysis of the Swedish Tax } \\
\text { Reforms 1989-1991 }\end{array}$ & 1993 \\
\hline
\end{tabular}




\begin{tabular}{|c|c|c|c|}
\hline 23 & Jonsson, Bo & $\begin{array}{l}\text { Forecasting Car Expenditures Using Household } \\
\text { Survey Data- A Comparison of Different Predictors }\end{array}$ & 1993 \\
\hline 24 & $\begin{array}{l}\text { Gennotte, Gerard and } \\
\text { Hayne Leland }\end{array}$ & Low Margins, Derivative Securitites and Volatility & 1993 \\
\hline 25 & $\begin{array}{l}\text { Boot, Arnoud W.A. and } \\
\text { Stuart I. Greenbaum }\end{array}$ & Discretion in the Regulation of U.S. Banking & 1993 \\
\hline 26 & $\begin{array}{l}\text { Spiegel, Matthew and } \\
\text { Deane J. Seppi }\end{array}$ & $\begin{array}{l}\text { Does Round-the-Clock Trading Result in Pareto } \\
\text { Improvements? }\end{array}$ & 1993 \\
\hline 27 & Seppi, Deane J. & $\begin{array}{l}\text { How Important are Block Trades in the Price Dis- } \\
\text { covery Process? }\end{array}$ & 1993 \\
\hline 28 & Glosten, Lawrence R. & $\begin{array}{l}\text { Equilibrium in an Electronic Open Limit Order } \\
\text { Book }\end{array}$ & 1993 \\
\hline 29 & $\begin{array}{l}\text { Boot, Arnoud W.A., } \\
\text { Stuart I Greenbaum and } \\
\text { Anjan V. Thakor }\end{array}$ & Reputation and Discretion in Financial Contracting & 1993 \\
\hline $30 \mathrm{a}$ & Bergström, Reinhold & $\begin{array}{l}\text { The Full Tricotomous Scale Compared with Net } \\
\text { Balances in Qualitative Business Survey Data - Ex- } \\
\text { periences from the Swedish Business Tendency } \\
\text { Surveys }\end{array}$ & 1993 \\
\hline $30 \mathrm{~b}$ & Bergström, Reinhold & $\begin{array}{l}\text { Quantitative Production Series Compared with } \\
\text { Qualiative Business Survey Series for Five Sectors of } \\
\text { the Swedish Manufacturing Industry }\end{array}$ & 1993 \\
\hline 31 & $\begin{array}{l}\text { Lin, Chien-Fu Jeff and } \\
\text { Timo Teräsvirta }\end{array}$ & $\begin{array}{l}\text { Testing the Constancy of Regression Parameters } \\
\text { Against Continous Change }\end{array}$ & 1993 \\
\hline 32 & $\begin{array}{l}\text { Markowski, Aleksander } \\
\text { and Parameswar Nan- } \\
\text { dakumar }\end{array}$ & $\begin{array}{l}\text { A Long-Run Equilibrium Model for Sweden. The } \\
\text { Theory Behind the Long-Run Solution to the } \\
\text { Econometric Model KOSMOS }\end{array}$ & 1993 \\
\hline 33 & $\begin{array}{l}\text { Markowski, Aleksander } \\
\text { and Tony Persson }\end{array}$ & $\begin{array}{l}\text { Capital Rental Cost and the Adjustment for the Ef- } \\
\text { fects of the Investment Fund System in the Econo- } \\
\text { metric Model Kosmos }\end{array}$ & 1993 \\
\hline 34 & $\begin{array}{l}\text { Kanis, Alfred and Bha- } \\
\text { rat Barot }\end{array}$ & $\begin{array}{l}\text { On Determinants of Private Consumption in Swe- } \\
\text { den }\end{array}$ & 1993 \\
\hline 35 & $\begin{array}{l}\text { Kääntä, Pekka and } \\
\text { Christer Tallbom }\end{array}$ & $\begin{array}{l}\text { Using Business Survey Data for Forecasting Swedish } \\
\text { Quantitative Business Cycle Varable. A Kalman } \\
\text { Filter Approach }\end{array}$ & 1993 \\
\hline 36 & $\begin{array}{l}\text { Ohlsson, Henry and } \\
\text { Anders Vredin }\end{array}$ & $\begin{array}{l}\text { Political Cycles and Cyclical Policies. A New Test } \\
\text { Approach Using Fiscal Forecasts }\end{array}$ & 1993 \\
\hline 37 & $\begin{array}{l}\text { Markowski, Aleksander } \\
\text { and Lars Ernsäter }\end{array}$ & $\begin{array}{l}\text { The Supply Side in the Econometric Model KOS- } \\
\text { MOS }\end{array}$ & 1994 \\
\hline 38 & $\begin{array}{l}\text { Gustafsson, Claes- } \\
\text { Håkan }\end{array}$ & $\begin{array}{l}\text { On the Consistency of Data on Production, Deliver- } \\
\text { ies, and Inventories in the Swedish Manufacturing } \\
\text { Industry }\end{array}$ & 1994 \\
\hline 39 & $\begin{array}{l}\text { Rahiala, Markku and } \\
\text { Tapani Kovalainen }\end{array}$ & $\begin{array}{l}\text { Modelling Wages Subject to Both Contracted In- } \\
\text { crements and Drift by Means of a Simultaneous- } \\
\text { Equations Model with Non-Standard Error Struc- } \\
\text { ture }\end{array}$ & 1994 \\
\hline 40 & $\begin{array}{l}\text { Öller, Lars-Erik and } \\
\text { Christer Tallbom }\end{array}$ & $\begin{array}{l}\text { Hybrid Indicators for the Swedish Economy Based } \\
\text { on Noisy Statistical Data and the Business Tendency } \\
\text { Survey }\end{array}$ & 1994 \\
\hline
\end{tabular}




\begin{tabular}{|c|c|c|c|}
\hline 41 & Östblom, Göran & $\begin{array}{l}\text { A Converging Triangularization Algorithm and the } \\
\text { Intertemporal Similarity of Production Structures }\end{array}$ & 1994 \\
\hline $42 \mathrm{a}$ & Markowski, Aleksander & $\begin{array}{l}\text { Labour Supply, Hours Worked and Unemployment } \\
\text { in the Econometric Model KOSMOS }\end{array}$ & 1994 \\
\hline $42 \mathrm{~b}$ & Markowski, Aleksander & $\begin{array}{l}\text { Wage Rate Determination in the Econometric } \\
\text { Model KOSMOS }\end{array}$ & 1994 \\
\hline 43 & $\begin{array}{l}\text { Ahlroth, Sofia, Anders } \\
\text { Björklund and Anders } \\
\text { Forslund }\end{array}$ & The Output of the Swedish Education Sector & 1994 \\
\hline $44 \mathrm{a}$ & Markowski, Aleksander & $\begin{array}{l}\text { Private Consumption Expenditure in the Econo- } \\
\text { metric Model KOSMOS }\end{array}$ & 1994 \\
\hline $44 \mathrm{~b}$ & Markowski, Aleksander & $\begin{array}{l}\text { The Input-Output Core: Determination of Inven- } \\
\text { tory Investment and Other Business Output in the } \\
\text { Econometric Model KOSMOS }\end{array}$ & 1994 \\
\hline 45 & Bergström, Reinhold & $\begin{array}{l}\text { The Accuracy of the Swedish National Budget Fore- } \\
\text { casts 1955-92 }\end{array}$ & 1995 \\
\hline 46 & Sjöö, Boo & $\begin{array}{l}\text { Dynamic Adjustment and Long-Run Economic } \\
\text { Stability }\end{array}$ & 1995 \\
\hline $47 \mathrm{a}$ & Markowski, Aleksander & $\begin{array}{l}\text { Determination of the Effective Exchange Rate in } \\
\text { the Econometric Model KOSMOS }\end{array}$ & 1995 \\
\hline $47 \mathrm{~b}$ & Markowski, Aleksander & $\begin{array}{l}\text { Interest Rate Determination in the Econometric } \\
\text { Model KOSMOS }\end{array}$ & 1995 \\
\hline 48 & Barot, Bharat & $\begin{array}{l}\text { Estimating the Effects of Wealth, Interest Rates and } \\
\text { Unemployment on Private Consumption in Sweden }\end{array}$ & 1995 \\
\hline 49 & Lundvik, Petter & Generational Accounting in a Small Open Economy & 1996 \\
\hline 50 & $\begin{array}{l}\text { Eriksson, Kimmo, Jo- } \\
\text { han Karlander and Lars- } \\
\text { Erik Öller }\end{array}$ & Hierarchical Assignments: Stability and Fairness & 1996 \\
\hline 51 & Url, Thomas & Internationalists, Regionalists, or Eurocentrists & 1996 \\
\hline 52 & Ruist, Erik & Temporal Aggregation of an Econometric Equation & 1996 \\
\hline 53 & Markowski, Aleksander & $\begin{array}{l}\text { The Financial Block in the Econometric Model } \\
\text { KOSMOS }\end{array}$ & 1996 \\
\hline 54 & Östblom, Göran & $\begin{array}{l}\text { Emissions to the Air and the Allocation of GDP: } \\
\text { Medium Term Projections for Sweden. In Conflict } \\
\text { with the Goals of } \mathrm{SO}_{2}, \mathrm{SO}_{2} \text { and NOX Emissions for } \\
\text { Year } 2000\end{array}$ & 1996 \\
\hline 55 & $\begin{array}{l}\text { Koskinen, Lasse, Alek- } \\
\text { sander Markowski, Pa- } \\
\text { rameswar Nandakumar } \\
\text { and Lars-Erik Öller }\end{array}$ & Three Seminar Papers on Output Gap & 1997 \\
\hline 56 & $\begin{array}{l}\text { Oke, Timothy and Lars- } \\
\text { Erik Öller }\end{array}$ & Testing for Short Memory in a VARMA Process & 1997 \\
\hline 57 & $\begin{array}{l}\text { Johansson, Anders and } \\
\text { Karl-Markus Modén }\end{array}$ & Investment Plan Revisions and Share Price Volatility & 1997 \\
\hline 58 & Lyhagen, Johan & $\begin{array}{l}\text { The Effect of Precautionary Saving on Consump- } \\
\text { tion in Sweden }\end{array}$ & 1998 \\
\hline 59 & $\begin{array}{l}\text { Koskinen, Lasse and } \\
\text { Lars-Erik Öller }\end{array}$ & $\begin{array}{l}\text { A Hidden Markov Model as a Dynamic Bayesian } \\
\text { Classifier, with an Application to Forecasting Busi- } \\
\text { ness-Cycle Turning Points }\end{array}$ & 1998 \\
\hline
\end{tabular}




\begin{tabular}{|c|c|c|c|}
\hline 60 & $\begin{array}{l}\text { Kragh, Börje and Alek- } \\
\text { sander Markowski }\end{array}$ & $\begin{array}{l}\text { Kofi - a Macromodel of the Swedish Financial Mar- } \\
\text { kets }\end{array}$ & 1998 \\
\hline 61 & $\begin{array}{l}\text { Gajda, Jan B. and Alek- } \\
\text { sander Markowski }\end{array}$ & $\begin{array}{l}\text { Model Evaluation Using Stochastic Simulations: The } \\
\text { Case of the Econometric Model KOSMOS }\end{array}$ & 1998 \\
\hline 62 & Johansson, Kerstin & Exports in the Econometric Model KOSMOS & 1998 \\
\hline 63 & Johansson, Kerstin & $\begin{array}{l}\text { Permanent Shocks and Spillovers: A Sectoral Ap- } \\
\text { proach Using a Structural VAR }\end{array}$ & 1998 \\
\hline 64 & $\begin{array}{l}\text { Öller, Lars-Erik and } \\
\text { Bharat Barot }\end{array}$ & $\begin{array}{l}\text { Comparing the Accuracy of European GDP Fore- } \\
\text { casts }\end{array}$ & 1999 \\
\hline 65 & $\begin{array}{l}\text { Huhtala, Anni and Eva } \\
\text { Samakovlis }\end{array}$ & $\begin{array}{l}\text { Does International Harmonization of Environ- } \\
\text { mental Policy Instruments Make Economic Sense? } \\
\text { The Case of Paper Recycling in Europe }\end{array}$ & 1999 \\
\hline 66 & Nilsson, Charlotte & $\begin{array}{l}\text { A Unilateral Versus a Multilateral Carbon Dioxide } \\
\text { Tax - A Numerical Analysis With The European } \\
\text { Model GEM-E3 }\end{array}$ & 1999 \\
\hline 67 & $\begin{array}{l}\text { Braconier, Henrik and } \\
\text { Steinar Holden }\end{array}$ & $\begin{array}{l}\text { The Public Budget Balance - Fiscal Indicators and } \\
\text { Cyclical Sensitivity in the Nordic Countries }\end{array}$ & 1999 \\
\hline 68 & Nilsson, Kristian & $\begin{array}{l}\text { Alternative Measures of the Swedish Real Exchange } \\
\text { Rate }\end{array}$ & 1999 \\
\hline 69 & Östblom, Göran & $\begin{array}{l}\text { An Environmental Medium Term Economic Model } \\
\text { - EMEC }\end{array}$ & 1999 \\
\hline 70 & $\begin{array}{l}\text { Johnsson, Helena and } \\
\text { Peter Kaplan }\end{array}$ & $\begin{array}{l}\text { An Econometric Study of Private Consumption } \\
\text { Expenditure in Sweden }\end{array}$ & 1999 \\
\hline 71 & $\begin{array}{l}\text { Arai, Mahmood and } \\
\text { Fredrik Heyman }\end{array}$ & $\begin{array}{l}\text { Permanent and Temporary Labour: Job and Worker } \\
\text { Flows in Sweden 1989-1998 }\end{array}$ & 2000 \\
\hline 72 & $\begin{array}{l}\text { Öller, Lars-Erik and } \\
\text { Bharat Barot }\end{array}$ & $\begin{array}{l}\text { The Accuracy of European Growth and Inflation } \\
\text { Forecasts }\end{array}$ & 2000 \\
\hline 73 & Ahlroth, Sofia & $\begin{array}{l}\text { Correcting Net Domestic Product for Sulphur Diox- } \\
\text { ide and Nitrogen Oxide Emissions: Implementation } \\
\text { of a Theoretical Model in Practice }\end{array}$ & 2000 \\
\hline 74 & $\begin{array}{l}\text { Andersson, Michael K. } \\
\text { And Mikael P. Greden- } \\
\text { hoff }\end{array}$ & $\begin{array}{l}\text { Improving Fractional Integration Tests with Boot- } \\
\text { strap Distribution }\end{array}$ & 2000 \\
\hline 75 & $\begin{array}{l}\text { Nilsson, Charlotte and } \\
\text { Anni Huhtala }\end{array}$ & $\begin{array}{l}\text { Is } \mathrm{CO}_{2} \text { Trading Always Beneficial? A CGE-Model } \\
\text { Analysis on Secondary Environmental Benefits }\end{array}$ & 2000 \\
\hline 76 & Skånberg, Kristian & $\begin{array}{l}\text { Constructing a Partially Environmentally Adjusted } \\
\text { Net Domestic Product for Sweden } 1993 \text { and } 1997\end{array}$ & 2001 \\
\hline 77 & $\begin{array}{l}\text { Huhtala, Anni, Annie } \\
\text { Toppinen and Mattias } \\
\text { Boman, }\end{array}$ & $\begin{array}{l}\text { An Environmental Accountant's Dilemma: Are } \\
\text { Stumpage Prices Reliable Indicators of Resource } \\
\text { Scarcity? }\end{array}$ & 2001 \\
\hline 78 & Nilsson, Kristian & $\begin{array}{l}\text { Do Fundamentals Explain the Behavior of the Real } \\
\text { Effective Exchange Rate? }\end{array}$ & 2002 \\
\hline 79 & Bharat, Barot & $\begin{array}{l}\text { Growth and Business Cycles for the Swedish Econ- } \\
\text { omy }\end{array}$ & 2002 \\
\hline 80 & Bharat, Barot & $\begin{array}{l}\text { House Prices and Housing Investment in Sweden } \\
\text { and the United Kingdom. Econometric Analysis for } \\
\text { the Period 1970-1998 }\end{array}$ & 2002 \\
\hline 81 & Hjelm, Göran & $\begin{array}{l}\text { Simultaneous Determination of NAIRU, Output } \\
\text { Gaps and Structural Budget Balances: Swedish Evi- } \\
\text { dence }\end{array}$ & 2003 \\
\hline
\end{tabular}




\begin{tabular}{|c|c|c|c|}
\hline 82 & $\begin{array}{l}\text { Huhtala, Anni and Eva } \\
\text { Samalkovis }\end{array}$ & Green Accounting, Air Pollution and Health & 2003 \\
\hline 83 & Lindström, Tomas & $\begin{array}{l}\text { The Role of High-Tech Capital Formation for } \\
\text { Swedish Productivity Growth }\end{array}$ & 2003 \\
\hline 84 & $\begin{array}{l}\text { Hansson, Jesper, Per } \\
\text { Jansson and Mårten Löf }\end{array}$ & $\begin{array}{l}\text { Business survey data: do they help in forecasting the } \\
\text { macro economy? }\end{array}$ & 2003 \\
\hline 85 & $\begin{array}{l}\text { Boman, Mattias, Anni } \\
\text { Huhtala, Charlotte Nils- } \\
\text { son, Sofia Ahlroth, Gö- } \\
\text { ran Bostedt, Leif Matt- } \\
\text { son and Peichen Gong }\end{array}$ & $\begin{array}{l}\text { Applying the Contingent Valuation Method in Re- } \\
\text { source Accounting: A Bold Proposal }\end{array}$ & \\
\hline 86 & Gren, Ing-Marie & $\begin{array}{l}\text { Monetary Green Accounting and Ecosystem Ser- } \\
\text { vices }\end{array}$ & 2003 \\
\hline 87 & $\begin{array}{l}\text { Samakovlis, Eva, Anni } \\
\text { Huhtala, Tom Bellander } \\
\text { and Magnus Svarteng- } \\
\text { ren }\end{array}$ & $\begin{array}{l}\text { Air Quality and Morbidity: Concentration-response } \\
\text { Relationships for Sweden }\end{array}$ & 2004 \\
\hline 88 & $\begin{array}{l}\text { Alsterlind, Jan, Alek } \\
\text { Markowski and Kristian } \\
\text { Nilsson }\end{array}$ & $\begin{array}{l}\text { Modelling the Foreign Sector in a Macroeconomet- } \\
\text { ric Model of Sweden }\end{array}$ & 2004 \\
\hline 89 & Lindén, Johan & The Labor Market in KIMOD & 2004 \\
\hline 90 & $\begin{array}{l}\text { Braconier, Henrik and } \\
\text { Tomas Forsfält }\end{array}$ & $\begin{array}{l}\text { A New Method for Constructing a Cyclically Ad- } \\
\text { justed Budget Balance: the Case of Sweden }\end{array}$ & 2004 \\
\hline 91 & $\begin{array}{l}\text { Hansen, Sten and To- } \\
\text { mas Lindström }\end{array}$ & Is Rising Returns to Scale a Figment of Poor Data? & 2004 \\
\hline 92 & Hjelm, Göran & $\begin{array}{l}\text { When Are Fiscal Contractions Successful? Lessons } \\
\text { for Countries Within and Outside the EMU }\end{array}$ & 2004 \\
\hline 93 & $\begin{array}{l}\text { Östblom, Göran and } \\
\text { Samakovlis, Eva }\end{array}$ & $\begin{array}{l}\text { Costs of Climate Policy when Pollution Affects } \\
\text { Health and Labour Productivity. A General } \\
\text { Equilibrium Analysis Applied to Sweden }\end{array}$ & 2004 \\
\hline 94 & $\begin{array}{l}\text { Forslund Johanna, Eva } \\
\text { Samakovlis and Maria } \\
\text { Vredin Johansson } \\
\end{array}$ & $\begin{array}{l}\text { Matters Risk? The Allocation of Government Subsi- } \\
\text { dies for Remediation of Contaminated Sites under } \\
\text { the Local Investment Programme }\end{array}$ & 2006 \\
\hline 95 & $\begin{array}{l}\text { Erlandsson Mattias and } \\
\text { Alek Markowski }\end{array}$ & $\begin{array}{l}\text { The Effective Exchange Rate Index KIX - Theory } \\
\text { and Practice }\end{array}$ & 2006 \\
\hline 96 & $\begin{array}{l}\text { Östblom Göran and } \\
\text { Charlotte Berg }\end{array}$ & The EMEC model: Version 2.0 & 2006 \\
\hline 97 & $\begin{array}{l}\text { Hammar, Henrik, } \\
\text { Tommy Lundgren and } \\
\text { Magnus Sjöström }\end{array}$ & $\begin{array}{l}\text { The significance of transport costs in the Swedish } \\
\text { forest industry }\end{array}$ & 2006 \\
\hline 98 & Barot, Bharat & $\begin{array}{l}\text { Empirical Studies in Consumption, House Prices } \\
\text { and the Accuracy of European Growth and Infla- } \\
\text { tion Forecasts }\end{array}$ & 2006 \\
\hline 99 & Hjelm, Göran & $\begin{array}{l}\text { Kan arbetsmarknadens parter minska jämviktsar- } \\
\text { betslösheten? Teori och modellsimuleringar }\end{array}$ & 2006 \\
\hline 100 & $\begin{array}{l}\text { Bergvall, Anders, To- } \\
\text { mas Forsfält, Göran } \\
\text { Hjelm, } \\
\text { Jonny Nilsson and Ju- } \\
\text { hana Vartiainen }\end{array}$ & $\begin{array}{l}\text { KIMOD 1.0 Documentation of NIER's Dynamic } \\
\text { Macroeconomic General Equilibrium Model of the } \\
\text { Swedish Economy }\end{array}$ & 2007 \\
\hline
\end{tabular}




\begin{tabular}{|c|c|c|c|}
\hline 101 & Östblom, Göran & $\begin{array}{l}\text { Nitrogen and Sulphur Outcomes of a Carbon Emis- } \\
\text { sions Target Excluding Traded Allowances - } \\
\text { An Input-Output Analysis of the Swedish Case }\end{array}$ & 2007 \\
\hline 102 & $\begin{array}{l}\text { Hammar, Henrik and } \\
\text { Åsa Löfgren }\end{array}$ & $\begin{array}{l}\text { Explaining adoption of end of pipe solutions and } \\
\text { clean technologies - Determinants of firms' invest- } \\
\text { ments for reducing emissions to air in four sextors } \\
\text { in Sweden }\end{array}$ & 2007 \\
\hline 103 & $\begin{array}{l}\text { Östblom, Göran and } \\
\text { Henrik Hammar }\end{array}$ & $\begin{array}{l}\text { Outcomes of a Swedish Kilometre Tax. An Analysis } \\
\text { of Economic Effects and Effects on NOx Emis- } \\
\text { sions }\end{array}$ & 2007 \\
\hline 104 & $\begin{array}{l}\text { Forsfält, Tomas, Johnny } \\
\text { Nilsson and Juhana } \\
\text { Vartianinen }\end{array}$ & $\begin{array}{l}\text { Modellansatser i Konjunkturinstitutets medelfrist- } \\
\text { prognoser }\end{array}$ & 2008 \\
\hline 105 & Samakovlis, Eva & $\begin{array}{l}\text { How are Green National Accounts Produced in } \\
\text { Practice? }\end{array}$ & 2008 \\
\hline 107 & $\begin{array}{l}\text { Forslund, Johanna, Per } \\
\text { Johansson, Eva Sama- } \\
\text { kovlis and Maria Vredin } \\
\text { Johansson }\end{array}$ & $\begin{array}{l}\text { Can we by time? Evaluation. Evaluation of the } \\
\text { government's directed grant to remediation in Swe- } \\
\text { den }\end{array}$ & 2009 \\
\hline 108 & $\begin{array}{l}\text { Forslund, Johanna } \\
\text { Eva Samakovlis, Maria } \\
\text { Vredin Johansson and } \\
\text { Lars Barregård }\end{array}$ & $\begin{array}{l}\text { Does Remediation Save Lives? } \\
\text { On the Cost of Cleaning Up } \\
\text { Arsenic-Contaminated } \\
\text { Sites in Sweden }\end{array}$ & 2009 \\
\hline 109 & $\begin{array}{l}\text { Sjöström, Magnus and } \\
\text { Göran Östblom }\end{array}$ & $\begin{array}{l}\text { Future Waste Scenarios for Sweden on the Basis of } \\
\text { a CGE-model }\end{array}$ & 2009 \\
\hline 110 & Österholm, Pär & $\begin{array}{l}\text { The Effect on the Swedish Real Economy of the } \\
\text { Financial Crisis }\end{array}$ & 2009 \\
\hline 111 & Forsfält, Tomas & $\begin{array}{l}\text { KIMOD } 2.0 \text { Documentation of changes in the } \\
\text { model from January } 2007 \text { to January } 2009\end{array}$ & 2009 \\
\hline 112 & Österholm, Pär & $\begin{array}{l}\text { Improving Unemployment Rate Forecasts Using } \\
\text { Survey Data }\end{array}$ & 2009 \\
\hline 113 & Österholm, Pär & $\begin{array}{l}\text { Unemployment and Labour-Force } \\
\text { Participation in Sweden }\end{array}$ & 2009 \\
\hline 114 & $\begin{array}{l}\text { Jonsson, Thomas and } \\
\text { Pär Österholm }\end{array}$ & $\begin{array}{l}\text { The Properties of Survey-Based } \\
\text { Inflation Expectations in Sweden }\end{array}$ & 2009 \\
\hline
\end{tabular}

